\title{
Laupacis aims to bring patient perspective to CMAJ
}

- Cite as: CMAJ 2019 October 21;191:E1171-2. doi: 10.1503/cmaj.1095816

Posted on cmajnews.com on Oct. 3, 2019; updated Oct. 9, 2019

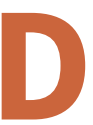

r. Andreas Laupacis, who took over as editor-in-chief of the CMAJ Group of publications on Oct. 7 , intends to continue his longstanding push to increase the involvement of patients in health care when he takes up his new post.

"I think it is important that the journal also involves patients in helping us journal has a very important history and reputation in Canada," he says. "It's an honour to be part of the people who are trying to continue that history."

Laupacis is a general internist who specializes in palliative care at St. Michael's Hospital, a scientist in the Li Ka Shing Knowledge Institute, and a

"It's hard to imagine a more suited person," says Dr. Joshua Tepper, CEO of North York General Hospital in Toronto. "He's one of the tiny number of people that immediately pops to mind."

Tepper has worked with Laupacis in several capacities, including as a researcher and as head of Health Quality Ontario, where Laupacis is the board chair. He says Laupacis has always worked hard to involve patients in health care decisions. "He's been a leader in patient engagement, first in research and then in the quality improvement industry, and in journalism at Healthy Debate, where he brought patients on to the editorial board."

Wendy Glauser, a Toronto-based health writer and CMAJ new contributor, worked with Laupacis at Healthy Debate for two years. She says he is a strong editor who thinks closely about everything he reads. "I think Andreas approaches any article he's editing with a great deal of curiosity and interest," he says. "His interjections are few but they are ones any writer is grateful for."

Laupacis is well-known as a mentor in medicine and science. Dr. Michelle Sholzberg, a clinical hematologist at St. Michael's Hospi-

Dr. Andreas Laupacis took over as editor-in-chief of the CMAJ Group of publications on Oct. 7.

think through the kind of material that we publish," he says.

Laupacis says his goal for CMAJ and the other CMAJ Group journals is to ensure they are a place where health service researchers and scientists in Canada feel their best work can be published, while also publishing things that are of interest to doctors not involved in research. "The professor in the Department of Medicine and the Dalla Lana School of Public Health at the University of Toronto. He has published hundreds of scientific articles and founded two health news websites, Healthy Debate and Faces of Health Care. Doctors, researchers and writers who know Laupacis have welcomed the news of his new role. tal whose thesis was supervised by Laupacis, says he was an inspiring mentor. "He provides tremendously thoughtful constructive feedback, while at the same time allowing you to make safe mistakes and learn things on your own," she says.

Laupacis is replacing Dr. Diane Kelsall, who has been interim editor-in-chief of CMAJ for three and a half years. Dr. Kelsall 
spent the first several months of her tenure contributing to a task force that set up a new governance structure to protect CMAJ's editorial independence and ensure the publication's well-being. Kelsall says she is proud of the way the staff pulled together to keep the journal going in the early period of the transition so that it didn't miss a single issue.

Kelsall developed a more modern publication format for CMAJ, with 50 weekly online issues and 12 magazine-style print issues per year. The journal was able to respond quickly to changing policy issues such as pharmacare and cannabis. "We can now do things quickly that would have been difficult to do three and a half years ago," she says. During the interim period the journal's multimedia, podcasts and social media offerings were also expanded.

Laupacis thanked Kelsall for her work as interim editor. "She's left the journal in a really good position for me to take over," he says.

Kelsall says she was "totally thrilled" when Laupacis' name came forward for the job. "He has a great track record of building forward-thinking organizations, and the ability to bring forward new and innovative ideas," she says. "The journal has changed so much to get ready for an editor like this."

Brian Owens, St. Stephen, NB 